\title{
Introduced clones of red grape varieties perspective for the Crimea
}

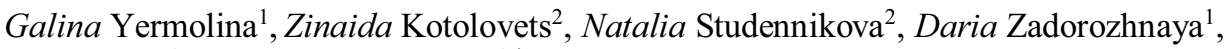 \\ Yuri Gerber ${ }^{1}$, and Dmitry Yermolin ${ }^{1, *}$ \\ ${ }^{1}$ V.I. Vernadskiy Crimean Federal University, Prospekt Vernadskogo 4, Simferopol, Republic of \\ Crimea, Russia \\ ${ }^{2}$ Magarach All-Russia National Research Institute for Viticulture and Wine-Making, st. Kirov 31, \\ Yalta, Republic of Crimea, Russia
}

\begin{abstract}
The research has shown that clones of the Cabernet Sauvignon variety R-5 and R-8 are distinguished by higher rates of fruiting. The average bunch weight in clones reaches $188.7 \pm 0.02 \mathrm{~g}(\mathrm{R}-5)$ and $177.3 \pm$ $2.6 \mathrm{~g}(\mathrm{R}-8)$, exceeding the control. The yield per bush is on average $5.34 \pm$ $0.21 \mathrm{~kg}$ and $4.25 \pm 0.07 \mathrm{~kg}$, exceeding the control by $1.54-1.23$ times. Shoot productivity in terms of bunch wet weight in the CabernetSauvignon R-5 clone is characterized as "high". The clone of the Merlot R3 variety has a high fruiting coefficient and a high fertility coefficient. The bunch weight of the clone reaches an average of $227.6 \pm 4.3 \mathrm{~g}$, the yield per bush is $6.3 \pm 0.1 \mathrm{~kg}$, exceeding the control. Shoot productivity in terms of bunch wet weight in the Merlot R-3 clone is characterized as "very high", in the control it is "high". The clone of the variety Bastardo Magarachsky VCR-1 has a higher fruiting coefficient than in the control. The average weight of a bunch of a clone reaches $247.7 \pm 1.4 \mathrm{~g}$ and exceeds the control $(186.3 \pm 9.14 \mathrm{~g})$. The yield per bush is within $4.62 \pm$ $0.2 \mathrm{~kg}$, exceeding the standard variety by $0.85 \mathrm{~kg}$. Shoot productivity in terms of bunch wet weight in Bastardo Magarachsky VCR-1 clone is characterized as "very high", in control this indicator is defined as "high". The degree of variability of most traits in populations of standard varieties is characterized as average, which indicates the heterogeneity of the population and the possibility of further identification of new biotypes. According to the technological assessment, the indicators of wine materials in terms of physicochemical and organoleptic indicators, the introduced clones of the studied varieties were superior to the control varieties. In terms of the volume fraction of ethyl alcohol, mass concentration of volatile and titratable acids, all wine materials met the requirements of regulatory documents. Tasting scores of Cabernet Sauvignon wine materials were 7.7-7.9 points. The highest marks were obtained for the sample generated from clone R-8. Wine materials produced from the Merlot variety were noted as high quality, with pronounced varietal characteristics.
\end{abstract}

\footnotetext{
*Corresponding author: dimayermolin@mail.ru
} 


\section{Introduction}

In the world practice of viticulture, the introduction of varieties and clones is quite widespread. Some varieties and their clones, transferred from traditional cultivation areas to other climatic zones, reveal their potential without reducing the quality of raw materials [1, $2,3]$. Of considerable interest for viticulture R Crimea are highly productive clones of red technical grape varieties widespread in Europe, the introduction and cultivation of which will ensure high profitability of the industry. In the farms of JSC "PJSC" Massandra ", over the past decades, vineyards have been laid by high-yielding clones of foreign selection of the Rauscedo VCR Cooperative Nursery, resistant to diseases of fungal etiology. The "Alushta" branch of JSC "PJSC" Massandra" is one of the leading farms in the viticulture and wine industry of the Republic of Crimea. An earlier analysis of the varietal and age structure of the vineyards of the economy, occupied by 29 varieties and clones of the technical direction of use, showed that the largest share in the range of industrial varieties is occupied by red grape varieties [4].

The aim of the research is to study the agrobiological and technological indicators of the introduced clones of red technical grape varieties in the conditions of the Alushta Valley.

\section{Materials and methods}

The studies were carried out in 2017-2020 in the industrial vineyards of the branch "Alushta" (Alushta) JSC "PJSC" Massandra "in the plantings of varieties and introduced clones. A clone of the variety Merlot R-3, 2011 planting, variety Merlot (control), 2006 planting. A clone of the Bastardo Magarach VCR-1 variety of 2008 planting, a control variety of 2010 planting. Clone of the Cabernet Sauvignon R-5 variety of 2011 planting, a clone of the Cabernet-Sauvignon R-8 variety of 2007 planting, control variety of the 2006 planting. Layout on plots $3 \times 1.25 \mathrm{~m}$, formation - spiral cordon AZOS-1 with free growth, plots without irrigation. The share of the clone Merlot R-3 accounts for $1.89 \%$ ( $8.59 \mathrm{ha}$ ) of the total area occupied by technical varieties, the share of the clone of the variety Bastardo Magarachsky VCR-1 - 1.36\% (6.18 ha). The specific gravity of the clone of the Cabernet Sauvignon R-5 variety is 7.51\% (34.34 ha), and the clone of the Cabernet Sauvignon R-8 variety is $0.5 \%(2.31 \mathrm{ha})$. The methods of analysis generally accepted in viticulture and oenochemistry were used in the work. The climate of the Alushta south coast is subMediterranean: arid, hot, with very mild winters. The average July temperature in Alushta is $+23.3^{\circ} \mathrm{C}$, in February $-+2.9^{\circ} \mathrm{C}$. The absolute minimum is $-18^{\circ} \mathrm{C}$, the absolute maximum is $+39^{\circ} \mathrm{C}$. The average annual air temperature is $+12.3^{\circ} \mathrm{C}$. The annual sum of active temperatures (above $+10^{\circ} \mathrm{C}$ ) reaches $3650-3714^{\circ} \mathrm{C}$. Alushta is characterized by a lack of atmospheric precipitation: $427 \mathrm{~mm}$ of them fall per year. Winter precipitation prevails [4].

\section{Results and discussions}

Table 1 shows the agrobiological indicators of red technical grape varieties and their clones, average for 2017-2019. 
Table 1. Agrobiological indicators of white technical grape varieties and their clones, 2017-2019.

\begin{tabular}{|c|c|c|c|c|c|c|c|c|c|c|}
\hline 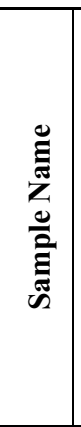 & 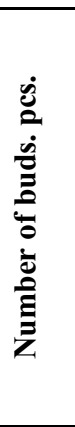 & 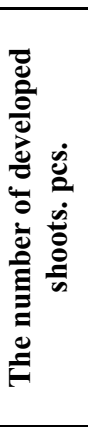 & 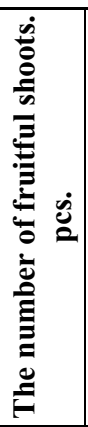 & 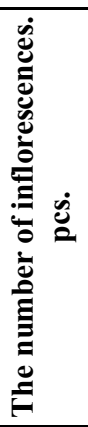 & 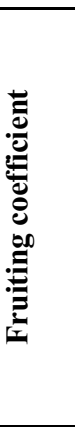 & 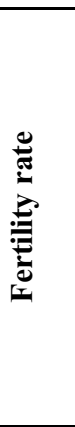 & 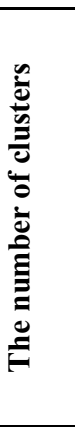 & 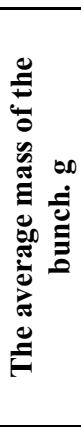 & 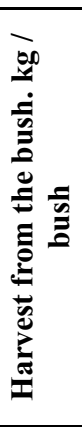 & 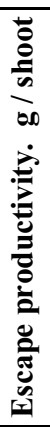 \\
\hline \multicolumn{11}{|c|}{ Cabernet Sauvignon } \\
\hline 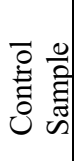 & 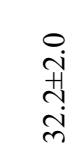 & $\begin{array}{l}0 \\
\text { i } \\
\stackrel{n}{N}\end{array}$ & 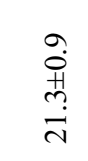 & $\begin{array}{l}\dot{\nabla} \\
\text { ì } \\
\text { m. } \\
\infty \\
\stackrel{N}{N}\end{array}$ & $\begin{array}{l}\text { I } \\
\dot{0} \\
+ \\
\dot{+} \\
\dot{0}\end{array}$ & $\begin{array}{l}\text { oे } \\
\dot{0} \\
+1 \\
m \\
\text { ?. }\end{array}$ & 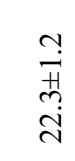 & 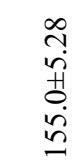 & $\begin{array}{l}n \\
0 \\
0 \\
0 \\
+ \\
\dot{n}\end{array}$ & $\begin{array}{l}0 \\
\stackrel{0}{1} \\
\stackrel{H}{1} \\
\frac{1}{-}\end{array}$ \\
\hline $\begin{array}{l}\partial^{\circ} \\
>\end{array}$ & $\stackrel{\infty}{\stackrel{0}{0}}$ & $\begin{array}{l}\infty \\
\stackrel{d}{~}\end{array}$ & $\stackrel{\circ}{\infty}$ & & 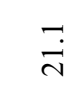 & $\stackrel{\searrow}{\mathrm{I}}$ & $a$ & $\begin{array}{l}\infty \\
i\end{array}$ & $\stackrel{\stackrel{ \pm}{ \pm}}{ }$ & $\stackrel{a}{\infty}$ \\
\hline $\begin{array}{l}n \\
\frac{1}{2} \\
0 \\
0 \\
0\end{array}$ & $\begin{array}{l}n \\
\text { nj } \\
0 \\
0 \\
0\end{array}$ & 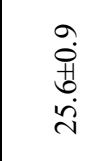 & 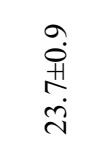 & $\begin{array}{l}\text { ت. } \\
\text { से } \\
\dot{m}\end{array}$ & 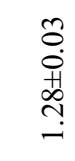 & 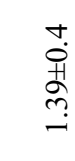 & 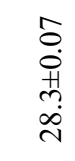 & $\begin{array}{l}0 \\
0 \\
+1 \\
0 \\
\infty \\
\infty\end{array}$ & 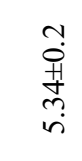 & $\begin{array}{l}\stackrel{ \pm}{\Xi} \\
\text { 苦 } \\
\stackrel{+}{+}\end{array}$ \\
\hline $\begin{array}{l}0^{\circ} \\
>\end{array}$ & $m_{\infty}^{m}$ & iे & $\stackrel{+}{\sigma}$ & 7 & $\frac{N}{n}$ & $\underset{F}{\stackrel{F}{*}}$ & $\stackrel{m}{r}$ & $\underset{i}{\stackrel{\Delta}{c}}$ & $\underset{0}{\infty}$ & $\stackrel{\sim}{\sim}$ \\
\hline $\begin{array}{l}\infty \\
\stackrel{1}{\alpha} \\
0 \\
\stackrel{0}{0} \\
\frac{0}{0}\end{array}$ & $\begin{array}{l}\stackrel{a}{0} \\
+ \\
\stackrel{+}{N} \\
\end{array}$ & $\begin{array}{l}\infty \\
0 \\
+ \\
m \\
\sim \\
\sim\end{array}$ & $\begin{array}{l}\hat{0} \\
\text { ti் } \\
\ddot{i}\end{array}$ & $\begin{array}{l}\stackrel{0}{0} \\
\text { H } \\
\stackrel{2}{2}\end{array}$ & 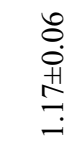 & $\begin{array}{l}\text { Oे } \\
\text { Oे } \\
\text { 莳 } \\
\text { I. }\end{array}$ & $\begin{array}{l}\stackrel{+}{\vdots} \\
\text { ț } \\
\dot{+}\end{array}$ & $\begin{array}{l}0 \\
\text { i } \\
\stackrel{+}{\sim} \\
\stackrel{-}{I}\end{array}$ & $\begin{array}{l}\overrightarrow{+} \\
\text { Ḧ } \\
\stackrel{+}{+} \\
\stackrel{+}{+}\end{array}$ & 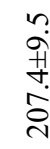 \\
\hline$>0^{\circ}$ & $\begin{array}{l}\dot{b} \\
\dot{n}\end{array}$ & $\underset{0}{0}$ & $\begin{array}{l}\infty \\
i\end{array}$ & $\stackrel{\circ}{\circ}$ & $\begin{array}{l}\circ \\
\infty \\
\infty\end{array}$ & $\stackrel{丶}{N}$ & $m_{\infty}^{m}$ & $\begin{array}{l}\stackrel{+}{\sim} \\
\stackrel{\sim}{r}\end{array}$ & $\underset{\sim}{\stackrel{f}{r}}$ & 9 \\
\hline \multicolumn{11}{|c|}{ Merlot } \\
\hline 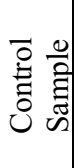 & $\begin{array}{l}n \\
\frac{n}{\dot{H}} \\
\tilde{N}\end{array}$ & 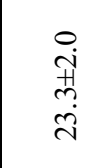 & $\begin{array}{l}\stackrel{+}{\dot{H}} \\
\text { ț } \\
\infty \\
\infty\end{array}$ & 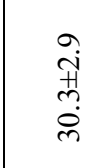 & 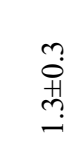 & 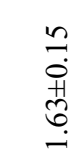 & $\begin{array}{l}\infty \\
\stackrel{+}{+} \\
m \\
ٍ \\
\sim\end{array}$ & $\begin{array}{l}\text { Na } \\
\text { Hे } \\
m \\
\infty \\
\infty\end{array}$ & 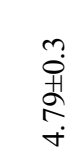 & 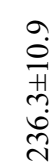 \\
\hline $\begin{array}{l}0^{\circ} \\
>\end{array}$ & $\stackrel{\infty}{a}$ & $\begin{array}{l}0 \\
\text { in }\end{array}$ & $\ddot{n}$ & فे & $\stackrel{\infty}{m}$ & $\begin{array}{l}\stackrel{0}{ } \\
\stackrel{\leftrightarrow}{n}\end{array}$ & $\stackrel{0}{=}$ & $\vec{\infty}$ & $\stackrel{\varrho}{0}$ & $\stackrel{\circ}{\infty}$ \\
\hline 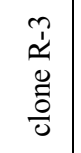 & 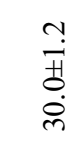 & 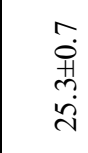 & $\begin{array}{l}0 \\
\dot{0} \\
\dot{1} \\
\dot{\vec{\lambda}}\end{array}$ & 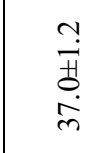 & $\begin{array}{l}3 \\
\stackrel{0}{0} \\
\stackrel{+}{+} \\
\stackrel{+}{+}\end{array}$ & $\begin{array}{l}\overrightarrow{0} \\
+1 \\
\stackrel{H}{0} \\
ت\end{array}$ & 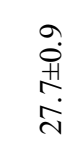 & 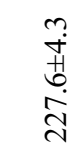 & 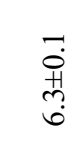 & $\begin{array}{l}\infty \\
\text { in } \\
\stackrel{+}{n} \\
m \\
m\end{array}$ \\
\hline
\end{tabular}




\begin{tabular}{|c|c|c|c|c|c|c|c|c|c|c|}
\hline$\stackrel{0}{\circ}^{\circ}$ & $\stackrel{6}{6}$ & $\stackrel{n}{\forall}$ & $\stackrel{r}{+}$ & $\stackrel{\nabla}{\sim}$ & $\ddot{n}$ & $\overrightarrow{0}$ & in & $\stackrel{m}{m}$ & $\tilde{n}$ & $\stackrel{\circ}{\circ}$ \\
\hline \multicolumn{11}{|c|}{ Bastardo Magarachsky } \\
\hline $\begin{array}{l}\stackrel{0}{0} \\
\text { : } \\
\tilde{W} \\
\text { : } \\
\text { : } \\
0\end{array}$ & $\begin{array}{l}\stackrel{+}{\mathrm{i}} \\
\stackrel{H}{\sim} \\
\stackrel{\sim}{\sim}\end{array}$ & $\begin{array}{l}\stackrel{0}{1} \\
\text { Hे } \\
\text { ஸे } \\
\text { ते }\end{array}$ & $\begin{array}{l}\stackrel{\sim}{H} \\
\stackrel{\sim}{N}\end{array}$ & 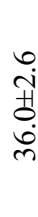 & $\begin{array}{l}\infty \\
0 \\
0 \\
+1 \\
\text { ஸे } \\
\end{array}$ & $\begin{array}{l}8 \\
0 \\
0 \\
\text { m } \\
n\end{array}$ & $\begin{array}{l}\text { ? } \\
\text { m } \\
\text { ¿ }\end{array}$ & $\begin{array}{l}\overrightarrow{0} \\
\text { in } \\
\text { తn } \\
\infty\end{array}$ & 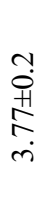 & $\begin{array}{l}\infty \\
\infty \\
\text { H. } \\
0 \\
\text { ते }\end{array}$ \\
\hline $\begin{array}{l}0^{\circ} \\
>\end{array}$ & $\stackrel{\overbrace{}}{\mathcal{C}}$ & 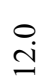 & $\stackrel{\circ}{\circ}$ & $\stackrel{\check{c}}{\check{c}}$ & $\stackrel{+}{\stackrel{\sim}{\sim}}$ & $\stackrel{0}{0}$ & $\stackrel{+}{\mathrm{I}}$ & $n$ & $\stackrel{?}{0}$ & $\stackrel{\sim}{ \pm}$ \\
\hline 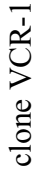 & 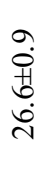 & 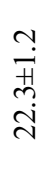 & $\begin{array}{l}0 \\
0 \\
\text { Hु } \\
\infty \\
0\end{array}$ & 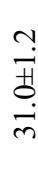 & 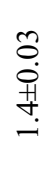 & 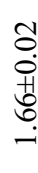 & $\begin{array}{l}\stackrel{0}{0} \\
+ \\
\dot{0} \\
0\end{array}$ & $\begin{array}{l}\frac{+}{+} \\
\stackrel{+}{+} \\
\stackrel{+}{\sim}\end{array}$ & 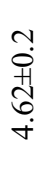 & $\begin{array}{l}\stackrel{9}{1} \\
\text { H } \\
\dot{0} \\
\dot{m}\end{array}$ \\
\hline $\begin{array}{l}\partial^{\circ} \\
>\end{array}$ & $\stackrel{\infty}{i}$ & $?$ & $\underset{\infty}{N}$ & $\stackrel{+}{\bullet}$ & $\stackrel{\infty}{m}$ & $\tilde{n}$ & $\vec{\infty}$ & 9 & $\stackrel{+}{\infty}$ & ले \\
\hline
\end{tabular}

The research showed that clones of the Cabernet Sauvignon variety R-5 and R-8, against the background of the standard variety, are distinguished by higher rates of fruiting (1.28-1.17) compared to the control. The average bunch weight in clones reaches $188.7 \pm$ $0.02 \mathrm{~g}(\mathrm{R}-5)$ and $177.3 \pm 2.6 \mathrm{~g}(\mathrm{R}-8)$, exceeding the control variety by $1.2-1.14$ times, respectively. The yield per bush is on average $5.34 \pm 0.21 \mathrm{~kg}$ and $4.25 \pm 0.07 \mathrm{~kg}$, exceeding the control by $1.54-1.23$ times. Shoot productivity in terms of bunch wet weight in Cabernet-Sauvignon R-5 clone is $241.6 \pm 1.1 \mathrm{~g} /$ shoot and is characterized as "high" in comparison with the control, in which this indicator is defined as "average" - 161.2 $\pm 17.6 \mathrm{~g}$ / shoot. The clone of the Cabernet Sauvignon R-8 variety for this indicator is at the control level $-207.4 \pm 9.5 \mathrm{~g} /$ shoot [5].

The clone of the Merlot R-3 variety is distinguished by a high fruiting coefficient of $1.47 \pm 0.0$, exceeding the control by 1.13 times, as well as a high fertility coefficient of 1.76 \pm 0.1 against the background of the control. The bunch weight of the clone reaches an average of $227.6 \pm 4.3 \mathrm{~g}$, exceeding the standard variety by 1.25 times, the yield per bush is $6.3 \pm 0.1 \mathrm{~kg}$, exceeding the control by $1.5 \mathrm{~kg}$. Shoot productivity in terms of bunch wet weight in the Merlot R-3 clone is $334.5 \pm 3.8 \mathrm{~g} /$ shoot and is characterized as "very high" in comparison with the control, in which this indicator is recorded as "high" - $236.3 \pm 10.9$ $\mathrm{g} /$ shoot.

In the clone of the Bastardo Magarachsky VCR-1 variety, the fruiting coefficient is 1.14 times higher than in the control and is $1.4 \pm 0.03$. The average weight of a bunch of a clone reaches $247.7 \pm 1.4 \mathrm{~g}$, which is 1.3 times higher than the control $(186.3 \pm 9.14 \mathrm{~g})$. The yield per bush is within $4.62 \pm 0.2 \mathrm{~kg}$, exceeding the standard variety by $0.85 \mathrm{~kg}$. The shoot productivity in terms of the wet weight of the bunch in the clone of the Bastardo Magarachsky VCR-1 variety is $346.7 \pm 7.9 \mathrm{~g} /$ shoot and is characterized as "very high" against the background of the control, in which this indicator is defined as "high" - $229.6 \pm$ $18.8 \mathrm{~g} /$ shoot. 
The grape plant has a clearly expressed quantitative variability of biological and economic characteristics. The carried out variational analysis made it possible to conclude (table 1) that the degree of variability of most traits in the populations of clones of Cabernet Sauvignon varieties R-5 (V = 2.2-8.3\%) and R-8 (V=2.54-8, 96\%), Merlot R-3 (V=2.0$6.6 \%)$, Bastardo Magarachsky VCR-1 (V = 1.9-9.3\%) is defined as weak, which indicates the genetic homogeneity of the presented clone populations introduced grape varieties in specific cultivation conditions.

The degree of variability of most traits in populations of standard varieties is characterized as average, which indicates the heterogeneity of the population and the possibility of further identification of new biotypes.

Wine materials were prepared of the studied clones using the mash fermentation scheme. Physicochemical indicators of wine materials are presented in table 2.

Analysis of the data presented in Table 2 indicates that the volume fraction of ethyl alcohol in the Cabernet Sauvignon samples was 13, -14.3\%, Merlot: 12.6-13.7\%, Bastardo Magarach 12.6-13.3 \%. Mass concentration of titratable acids for Cabernet-Sauvignon wine materials 6.0-6.4 g / dm3, Merlot: 6.8-6.9 g / dm3, Bastardo Magarach: 6.2-6.4 g / dm3. The mass concentration of volatile acids for wine materials of the Cabernet-Sauvignon variety was 0.5-0.7 g / dm3, Merlot: 0.7-0.9 g / dm3, Bastardo Magarachsky: 0.6-0.9 g / $\mathrm{dm} 3$. In general, in terms of the volume fraction of ethyl alcohol, the mass concentration of volatile and titratable acids, all wine materials met the requirements of regulatory documents.

The mass concentration of phenolic and coloring substances in the clones of CabernetSauvignon, Merlot and Bastardo Magarachsky exceeded those of traditional varieties. In general, the value of these indicators of all studied wine materials corresponded to the values typical for the Western European ecological-geographical group [5-15].

Table 2. Physico-chemical and organoleptic characteristics of wine materials from white technical grape varieties and their clones, 2018-2020.

\begin{tabular}{|c|c|c|c|c|c|c|c|}
\hline $\begin{array}{c}\text { Sample } \\
\text { Name }\end{array}$ & 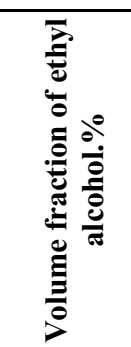 & 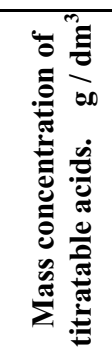 & 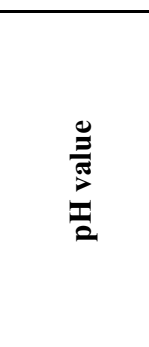 & 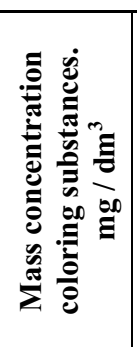 & 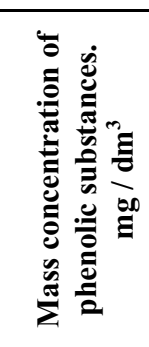 & 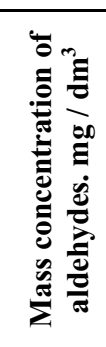 & 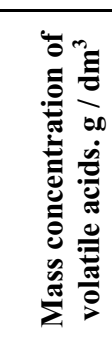 \\
\hline \multicolumn{8}{|c|}{ Cabernet Sauvignon } \\
\hline $\begin{array}{l}\text { Control } \\
\text { Sample }\end{array}$ & $13.1 \pm 0.4$ & $6.0 \pm 0.3$ & $3.20 \pm 0.04$ & $193 \pm 21$ & $1350 \pm 120$ & $57 \pm 14$ & $0.7 \pm 0.2$ \\
\hline clone R-5 & $14.2 \pm 0.3$ & $6.4 \pm 0.3$ & $3.12 \pm 0.09$ & $198 \pm 17$ & $1460 \pm 150$ & $51 \pm 13$ & $0.6 \pm 0.3$ \\
\hline clone R-8 & $14.3 \pm 0.2$ & $6.2 \pm 0.4$ & $3.11 \pm 0.08$ & $201 \pm 19$ & $1520 \pm 155$ & $54 \pm 12$ & $0.5 \pm 0.3$ \\
\hline \multicolumn{8}{|c|}{ Merlot } \\
\hline $\begin{array}{l}\text { Control } \\
\text { Sample }\end{array}$ & $12.6 \pm 0.4$ & $6.9 \pm 0.3$ & $3.08 \pm 0.09$ & $187 \pm 19$ & $1420 \pm 120$ & $68 \pm 14$ & $0.9 \pm 0.2$ \\
\hline clone R-3 & $13.7 \pm 0.7$ & $6.8 \pm 0.6$ & $3.08 \pm 0.08$ & $196 \pm 17$ & $1490 \pm 135$ & $56 \pm 15$ & $0.7 \pm 0.2$ \\
\hline \multicolumn{8}{|c|}{ Bastardo Magarachsky } \\
\hline $\begin{array}{l}\text { Control } \\
\text { Sample } \\
\end{array}$ & $12.6 \pm 0.1$ & $6.2 \pm 0.5$ & $3.22 \pm 0.10$ & $183 \pm 11$ & $1340 \pm 115$ & $47 \pm 19$ & $0.9 \pm 0.3$ \\
\hline clone R-3 & $13.3 \pm 0.3$ & $6.4 \pm 0.4$ & $3.20 \pm 0.11$ & $196 \pm 14$ & $1450 \pm 125$ & $54 \pm 16$ & $0.6 \pm 0.1$ \\
\hline
\end{tabular}

Tasting assessments of the studied wine materials are presented in Figure 1. 
Figure 1 shows that the tasting ratings of Cabernet Sauvignon wine materials were 7.77.9 points. The highest marks were obtained for the sample generated from clone R- 8 . Wine materials produced from the Merlot variety were noted as high quality, with pronounced varietal characteristics. The wine material Merlot R-3 received an assessment of 7.9 points, and the wine material Merlot from the traditional variety was 7.75 points, which was associated with a less pronounced varietal aroma. Higher tasting marks were given to the wine material Bastardo Magarachsky, made from the introduced clone.

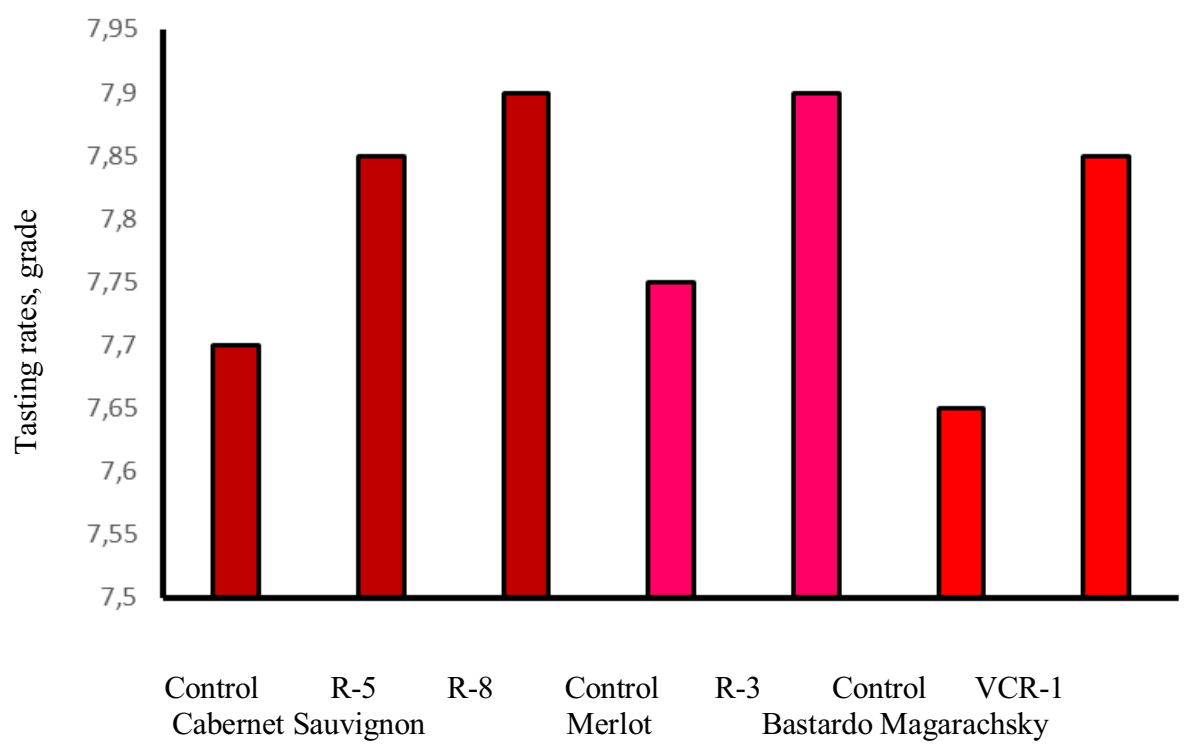

Fig. 1. Tasting assessments of the studied wine materials.

\section{Conclusions}

The presented introduced clones of classic grape varieties cultivated in the Alushta Valley surpass the standard varieties in terms of bunch weight, bush yield, shoot productivity in terms of bunch wet weight, which provides a basis for their further reproduction and introduction. According to the technological assessment, the physical, chemical and organoleptic indicators of wine materials, the introduced clones of Cabernet Sauvignon, Merlot and Bastardo Magarachsky varieties exceeded the indicators of wine materials from traditional varieties.

\section{References}

1. Ya. Yalanetskiy, N.A. Ganay, G.V. Taran, M.N. Borisenko, V.A. Zagorouiko, V.I. Ivanchenko, Magarach. Viticulture and winemaking 3, 21-23 (2011) https://elibrary.ru/download/elibrary_23577190_27956826.pdf

2. Z.V. Kotolovets, D.V. Yermolin, G.V. Yermolina, Magarach. Viticulture and $\begin{array}{lllll}\text { winemaking } & 3 & 16-17 & \text { (2017) } & \text { https:// elibrary.ru/ }\end{array}$ download/elibrary_30016935_49292275.pdf

3. Z.V. Kotolovets, D.V. Yermolin, G.V. Yermolina, Magarach. Viticulture and winemaking

4, $8-10$

(2017)

https://elibrary.ru/download/elibrary_30728765_97264077.pdf 
4. N.L. Studennikova, Z.V. Kotolovets, V.V. Likhovskoy, P.V. Beisel, L.P. Troshin, Polythematic online scientific journal of Kuban state agrarian university 148, 142-152 (2019) https://www.elibrary.ru/download/elibrary_37084157_34544503.pdf

5. L.M. Solovieva, Y.V. Grishin, A.N. Kazak, N.N. Oleinikov, P.V. Chetyrbok, Journal $\begin{array}{llll}\text { of } & \text { Physics: } & \text { Conference } & \text { Series }\end{array}$ https://iopscience.iop.org/article/10.1088/1742-6596/1703/1/012048/pdf

6. S.V. Levchenko, E. Ostroukhova, I. Peskova, Acta Horticulturae 1380, 169-180 (2021) doi: 10.17660/ActaHortic.2021.1308.25

7. S.V. Levchenko, V.V. Likhovskoi, I.A. Vasylyk, V.A. Volynkin, Acta Horticulturae 1308, 181-187 (2021) 10.17660/ActaHortic.2018.1205.38

8. E. Ostroukhova, I. Peskova, M. Vyugina, S.V. Levchenko, Acta Horticulturae 1205(2), 327-337 (2018) doi: 10.17660/ActaHortic.2018.1205.38

9. M. Roach, D. Johnson, J. Bohlmann, H. J. Van Vuuren, S. Jones, I. Pretorius, S. Schmidt, A. Borneman, PLOS Genetics, 1-24 (2018) doi: 10.1371/journal.pgen.1007807

10. G.P. Zaitsev, V.Y. Mosolkova, Yu.V. Grishin, Yu.A. Ogai, Magarach. Viticulture and winemaking,

4, 28-30

https://www.elibrary.ru/download/elibrary_22800721_45477273.pdf

(2014)

11. J. Balík, M. Kumšta, O. Rop, Chemical Papers 67, 1285-1292 (2013) DOI: 10.2478/s11696-013-0378-9

12. Ke Zhang, Lin Yuan, Qian Li, Rui Wang, Zhen-Zhen Zhang, OENO One 53 (2019) DOI: https://doi.org/10.20870/oeno-one.2019.53.3.2460

13. K. Bindon, S. Kassara, Y. Hayasaka, A. Schulkin, P. Smith, J. Agric. Food Chem. 62, 11582-1159 (2014) DOI: 10.1021/jf503922h

14. D. Yermolin, G. Yermolina, Yu.B. Gerber, D. Zadorozhnaya, Z. Kotolovets, E3S Web of Conferences 08002 (2020) doi: 10.1051/e3sconf/202017508002

15. D. Yermolin, D. Zadorozhnaya, G. Yermolina, V. Ivanchenko, P. Dogoda, IOP Conference Series: Earth and Environmental Science 012070 (2019) doi: $10.1088 / 1755-1315 / 403 / 1 / 012070$ 